\title{
3D Printing as an Object of Legal Protection
}

\author{
Natalya Yushchenko ${ }^{1, *}$, Rustem Magizov ${ }^{1}$, and Elmira Gumerova ${ }^{2}$ \\ ${ }^{1}$ Naberezhnye Chelny Institute Kazan Federal University, 423812 Naberezhnye Chelny, Russia \\ ${ }^{2}$ Kazan Innovative University named after V.G.Timiryasov, Naberezhnye Chelny Branch, 423800 \\ Naberezhnye Chelny, Russia
}

\begin{abstract}
The article discusses the formation of a new approach to the statutory regulation of 3D printing, an uncommon object of civil matters. Creating a product with the help of such technology not only by an entrepreneur but also by any person, can in practice cause some issues in protecting all participants' rights during the $3 \mathrm{D}$ printing process. $3 \mathrm{D}$ printing is regarded as a complex object, so its characteristics are determined. Additionally, possible ways of resolving legislative gaps are proposed, such as: defining the concept of the manufacturer, supplier, seller, and consumer of 3D printed products; developing their rights and responsibilities; establishing quality requirements for 3D printed elements; and adopting clear rules on liability and consumer protection. Due to the widespread use of digital technologies, Russian legislation requires a thorough reconsideration and early reform.
\end{abstract}

\section{Introduction}

The development of digital technologies opens up new opportunities for humanity, but at the same time, requires statutory regulation. One of such technologies that are being actively implemented not only in industrial production but also in our daily life, is 3D printing.

Production of three-dimensional, complex, geometric structures using 3D printing is used both to ensure rapid prototyping in industry, as well as the production of personalized household items, such as bicycle parts, electrical components and jewelry [1]. Beyond its application in the industrial and consumer sectors, 3D printing is used in science and education. For example, archaeologists and anthropologists produce copies of rare artifacts or fossils that can be stored and demonstrated in the educational process [2].

3D printing was first described in 1986 by Charles V. Hull. In his method, which he called "stereolithography," thin layers of material that can be solidified with ultraviolet light were successively printed in layers to form a solid, three-dimensional structure [3]. The next step was 3D bio-printing as a form of tissue engineering, which was made possible thanks to recent achievements in $3 \mathrm{D}$ printing technology, cell biology, and materials science.

\footnotetext{
* Corresponding author: yushchenko31@rambler.ru
} 


\section{Methods and essence of 3D Printing}

\subsection{Concept of 3D Printing}

The term 3D printing covers a variety of processes in which material is joined or solidified under computer control to create a three-dimensional object. In the near future, scientific progress will allow us to make online purchases not only of the product itself but of files for 3Dprinting. Moreover, the improvement of technical devices (computers, smartphones, tablets, etc.) makes it increasingly possible to scan any object in 3D and print it.

$3 \mathrm{D}$ printing or additive manufacturing usually refers to rapid prototyping. Some experts make a distinction between additive manufacturing and 3D printing. In particular, it is noted that additive production includes $3 \mathrm{D}$ printing and other technologies or other aspects of the production process.

Additive Manufacturing (AM) is the technology that builds three-dimensional objects by adding layer-upon-layer of material, be it plastic, metal, concrete, or human tissue. Common to AM technology is the use of a computer, 3D modeling software (Computer Aided Design or CAD), machine equipment and layering material. Once a CAD sketch is produced, the $\mathrm{AM}$ equipment reads in data from the $\mathrm{CAD}$ file and lays down or adds successive layers of liquid, powder, sheet material or other, in a layer-upon-layer fashion to fabricate a three-dimensional object [6]. The term AM encompasses many technologies including such subsets like 3D Printing, Rapid Prototyping (RP), Direct Digital Manufacturing (DDM), layered manufacturing and additive fabrication.

$3 \mathrm{D}$ printing is carried out on a 3D printer - a computer controlled machine that applies a layer-upon-layer method to create an object [7].

Thus, 3D printing is a term used to describe a range of digital manufacturing technologies [8].

\subsection{Features of 3D Printing}

$3 \mathrm{D}$ printing, as a single technology for digital production of things, has the following features: 1) the availability of a 3D printer, a technical device for reproducing things; 2) the availability of a 3D file or software for 3D modeling; 3 ) the availability of a computer or other technical device for playing a 3D file or software for 3D modeling; 4) the availability of raw materials for the production of things.

Place the figure as close as possible after the point where it is first referenced in the text. If there is a large number of figures and tables it might be necessary to place some before their text citation.

\subsection{The impact of $3 d$ printing on current legislation}

Russian legislation lacks legal regulation of 3D printing, a process for producing an object that requires both private and public law regulations. Currently, the contractual relationship is built in connection with the acquisition of a $3 \mathrm{D}$ printer and/or software for $3 \mathrm{D}$ printing and a technical device.

Society faces a number of issues that require legislative regulation: the formation of new contractual structures, the protection of trademarks, the definition of responsible persons and the boundaries of the offense, the establishment of a causal link, the security in 3D printing, etc.

Before scanning an object and 3D printing it, the following issues require legal resolution. First, who is responsible for the violation of intellectual property rights: a 3D 
printing service provider, a customer or the manufacturer of the 3D printer? [9] Second, is there a difference in prosecution if a customer for $3 \mathrm{D}$ printing and/or $3 \mathrm{D}$ printing manufacturer is an individual or an entrepreneur? Third, what if an object is produced as a result of $3 \mathrm{D}$ printing, and the creation, storage and use of it require a license and/or certification or another permissive document from state authorities? For example, the acquisition and storage of weapons under Russian law requires a license. The absence of a license for weapons in Russia is a criminal offense. Suppose a person who does not have a license for a weapon has 3D printed it. There are even more questions. From which moment is the weapon considered to be acquired without a license: from the end of the production process or from the moment of downloading the file for $3 \mathrm{D}$ printing? Will $3 \mathrm{D}$ printed weapons be considered as weapons protected by the state?

Creating a physical object in the virtual world based on digital files requires a new definition of a "manufacturer", "supplier", "seller" and "consumer" of 3D printed products. Technologically, the process of 3D printing in industrial production can be represented as follows: 1) the supplier provides the material to the manufacturer, where it is tested and the product design is approved; 2) the manufacturer performs $3 \mathrm{D}$ printing remotely from the supplier of the material and design; 3) the final product undergoes a quality check and is sent to the seller or end user [10]. The end user here can be both a manufacturer and a seller. The consumer can purchase a 3D printer and can create products for personal use or for resale using one's own skills, or by buying or obtaining a 3D file using a technical device.

\section{Optimal solutions}

In law enforcement practice, there may be questions about the identification of the person responsible for the quality of products manufactured using $3 \mathrm{D}$ printing. So, in the event of the harm posed by $3 \mathrm{D}$ printed products, who should be considered as its manufacturer: the person who has directly printed the product, the manufacturer of the $3 \mathrm{D}$ printer, the supplier of the file or the seller (manufacturer) of the technical device? Here is another case scenario. For example, a malfunctioning part of a manufacturing machine has been replaced by a $3 \mathrm{D}$ printed part. The warranty obligations of the seller (manufacturer) of the machine, as a general rule, apply if the repair is carried out with original spare parts. In this case, will the received $3 \mathrm{D}$ parts file from the manufacturer or the scanned parts be recognized as original parts?

\subsection{Responsibility for product quality in the US}

For example, US law lists the reasons for compensation in case of product liability. A product is defective when, at the time of sale or distribution, it:

1) contains a manufacturing defect;

2) is defective in design, or

3 ) is defective because of inadequate instructions or warnings.

A product:

a) contains a manufacturing defect when the product departs from its intended design even though all possible care was exercised in the preparation and marketing of the product;

b) is defective in design when the foreseeable risks of harm posed by the product could have been reduced or avoided by the adoption of a reasonable alternative design by the seller or another distributor, or a predecessor in the commercial chain of distribution, and the omission of the alternative design renders the product not reasonably safe; 
c) is defective because of inadequate instructions or warnings when the foreseeable risks of harm posed by the product could have been reduced or avoided by the provision of reasonable instructions or warnings by the seller or another distributor, or a predecessor in the commercial chain of distribution, and the omission of the instructions or warnings renders the product not reasonably safe [11]

\subsection{The rule of "strict liability"}

The "strict liability" rule in the United States, which most courts use, can be summarized as follows:

1)One who sells any product in a defective condition unreasonably dangerous to the user or consumer or to his property is subject to liability for physical harm thereby caused to the ultimate user or consumer, or to his property, if

a) the seller is engaged in the business of selling such a product, and

b)it is expected to and does reach the user or consumer without substantial change in the condition in which it is sold.

2)This rule is applied, even if

a)the seller has exercised all possible care in the preparation and sale of his product, and

b)the user or consumer has not bought the product from or entered into any contractual relation with the seller.

The definition of "strict liability", however, is limited to physical damage. Many courts have decided that a person who has suffered economic damage should resort to warranty law [12]. Thus, "strict liability" is aimed at returning to the source through the distribution chain and placing the responsibility on the creator of the product. But the consumer may participate in the production chain as well. Although over time this will have a very significant impact on the redefinition of the production form in the country, it also raises concerns that existing obligations that are now imposed on traditional producers may be related to those whom we refer to as a standard consumer [13]. However, this new production technology creates legal uncertainty and can shift the legal balance in the area of responsibility in product quality.

\section{Conclusions}

It is necessary to establish 3D printing as an independent object of civil rights and to set its specific features. In the legislation on consumer protection, it is important to introduce a separate section that defines the rights, duties, and responsibilities of the manufacturer, supplier, seller and consumer of 3D printed products. It is necessary to provide requirements for the quality of raw materials, equipment for the production of $3 \mathrm{D}$ printing, as well as the rules for checking the quality of the products produced when the production is carried out by a professional participant.

The increasing availability of 3D printing technology for people requires resolving the security issue regarding the product it creates, as well as the possibility to modify, customize, and improve a 3D file or software for 3D modeling.

Russian society faces the question of whether the current legislation is capable of solving all the issues discussed in the article or whether they need to be modified. It seems that the norms of Russian legislation should be adapted for 3D printing and additive manufacturing. The application of general terms for the responsibility of the product quality in $3 \mathrm{D}$ printing is no longer true to reality. Moreover, the definitions of the manufacturer, supplier, seller, and consumer of 3D printed products require reconsideration, as well as their rights and obligations. It is important to balance the interests of the participants in these relations and determine the scope of responsibility for each of them. In the near 
future, the rules for 3D printing and additive manufacturing will become standard in our society, and the manufacturer, supplier, seller and consumer of 3D printing and additive manufacturing will take their place among traditional subjects of legal relations. Extensive use of this technology requires the safety of a 3D printed product and reliable consumer protection

\section{Acknowledgements}

The work is performed according to the Russian Government Program of Competitive Growth of Kazan Federal University.

\section{References}

1. E. Malone, H. Lipson, Rapid Prototyping J. 13, 245 (2007)

2. T.Allard, M.Sitchon, R.Sawatzky, R.Hoppa, Archaeology and Cultural Heritage, 42 (2005)

3. C.W. Hull, Apparatus for production of three-dimensional objects by stereolithography, US 4575330 A Google Patents (1986)

4. J..Excell, The rise of additive manufacturing. The Engineer. Retrieved, October (2013), https://www.researchgate.net/

5. P. Zelinski, Additive manufacturing and $3 D$ printing are two different things, August (2017), https://www.additivemanufacturing.media/

6. What is Additive Manufacturing? AM Directory, May (2019) Available at: $\mathrm{http}: / /$ additivemanufacturing.com/basics/

7. 3D printing. Wikipedia, May (2019), https://ru.wikipedia.org/

8. P. Reeves, D. Mendis, The Current Status and Impact of $3 D$ Printing within the Industrial Sector: An Analysis of Six Case Studies, Intellectual Property Office UK, 2 (2015), www.gov.uk/

9. Hub Dohmen, Legal implications of $3 \mathrm{D}$ printing in $3 \mathrm{D}$ fab+print magazine, https://3dfabprint.com/

10. J. P. Comerford, E.P. Belt, 3DP, AM, 3DS and Product Liability, 55 Santa Clara L. Rev., 821 (2015), http://digitalcommons.law.scu.edu/

11. Uniform Commercial Code (UCC), § 402A. Special Liability of Seller of Product for Physical Harm to User or Consumer, https://www.law.cornell.edu/

12. Law of Commercial Transactions, Saylor Academy (2012), https://saylordotorg.github.io/

13. N.F. Engstrom, 3-D Printing and Product Liability: Identifying the Obstacles, 162 the University of Pennsylvania Law Review Online 352013 (2013), https://www.pennlawreview.com/ 